ORIGINAL ARTICLE

\title{
Effectiveness of Tramadol in Controlling Postanesthetic Shivering
}

\author{
MUHAMMAD ARIF BALOCH ${ }^{1}$, NAZEER AHMED ${ }^{2}$, MUHAMMAD SHARIF ${ }^{3}$, ZAFARULLAH $^{4}$, YASIR REDA TOBLE ${ }^{5}$ \\ ${ }^{1}$ Specialist Anesthetist, Hamad Medical Corporation (HMC) Qatar. \\ ${ }^{2}$ Associate consultant Anesthetist, Hamad Medical Corporation (HMC), Qatar. \\ ${ }^{3}$ Registrar Anesthesia, Lateefa Hospital Dubai. \\ ${ }^{4}$ (FCPS) \\ ${ }^{5}$ Senior consultant Anesthetist, HMC Qatar. \\ Correspondence to: Arif Baloch, Email: marifbaloch@gmail.com
}

\begin{abstract}
Objectives: The objective of the study was to assess the effectiveness of intravenous tramadol in controlling post anesthetic shivering and to assess which of the dose of drug is safe and effective.

Material and Methods: In this study we included 120 patients age $>18$ years of ASA class I \& II who underwent any surgical procedure under spinal/general anesthesia. Patients were divided into 3 groups of equal size of 40 subjects. Group A; in these patients tramadol $0.25 \mathrm{mg} / \mathrm{kg} \mathrm{I/V}$ was given for shivering management. Group B; in these patients Tramadol $0.5 \mathrm{mg} / \mathrm{kg} \mathrm{I/V}$ was given and Group C (control group); in these patients normal saline $0.05 \mathrm{ml} / \mathrm{kg} \mathrm{I} / \mathrm{V}$ was given. The adequate control of shivering was the main study objective. Side effects of tramadol at different doses were also observed.

Results: At five minutes, Grade 0,1 and 2 shivering were observed in 23 patients in group A and 31 patients in group B while in group C grade 3 and 4 shivering were observed. High grade (3 and 4$)$ shivering were significantly high in group $C$ than group $A$ and $B(p$-value $=0.005)$. Similarly, at 10 minutes, grade 3 and 4 shivering were significantly high in group $C$ than group $A$ and $B$ (p-value 0.005$)$.

Conclusion: IV $0.25 \mathrm{mg} / \mathrm{Kg}$ is an effective option for control of post-anesthesia shivering with minimal side effect profile. So low dose tramadol can be used as a first option for post-anesthesia shivering control.

Keywords: Anesthesia, Shivering, Tramadol.
\end{abstract}

\section{INTRODUCTION}

Shivering after anesthesia is a frequent consequence, with rates ranging from $40 \%$ to $70 \% .^{1}$ It is characterized as tremor-like hyperactivity of the skeletal muscles that is spontaneous, involuntary, and oscillatory. ${ }^{2}$ The shivering is uncomfortable for both the patient and the surgeon due to shivering-induced strong muscular movements and an awake condition throughout the procedure. It raises heart rate $(\mathrm{HR})$, oxygen consumption, carbon dioxide generation, and blood pressure. ${ }^{3,4}$ These may be harmful, especially in people with poor cardiac output, since they increase cardiac workload. It has the potential to worsen wound pain, slow wound healing, and postpone hospital discharge. Shivering also causes intraocular and intracranial pressures to rise, interfering with perioperative vital monitoring. Thermoregulatory impairment is caused by general anesthesia, which produces an increase in heat sensitivity and a reduction in cold response threshold. Heat loss and core to peripheral redistribution of body heat leads the core temperature to drop, requiring greater shivering to avoid hypothermia. Heat loss was enhanced by block during spinal anesthesia.5,6 The above-mentioned complications, together with the high prevalence of postanesthesia shivering, make its prevention essential.

Prophylaxis with intravenous (IV) tramadol has been shown to reduce the incidence of postanesthesia shivering in a dose-dependent manner. ${ }^{7,8}$ However, there is a paucity of research comparing the antishivering effectiveness of various dosages of IV tramadol. As a result, the current prospective randomized controlled trial was designed to determine the antishivering effectiveness of two regularly used dosages of IV tramadol.

\section{MATERIALS AND METHODS}

This prospective, randomized clinical trial was conducted in department of Anesthesiology, Civil Hospital Karachi from March-2018 to Jan-2019. A total of 120 Patients of age 18 years and above, with ASA I and II, who developed postanesthesia grade 2, 3 or 4 shivering were included. Patients with known tramadol hypersensitivity, having body temperature $>100{ }^{\circ} \mathrm{F}$ or $<97^{\circ} \mathrm{F}$ at the time of anesthesia induction, and patients in whom intra-muscular meperidine was administrated within one hour of induction of anesthesia were excluded.

These were randomized into 3 groups of equal size of 40 subjects. An anesthetic assistant, who was not involved in the study, picked out one of the 120 envelops and this was continued till the completion of sample size. Then the patient allocated to the intervention group according to lottery drawn.

Group A; in these patients tramadol $0.25 \mathrm{mg} / \mathrm{kg} \mathrm{I/V}$ was given for shivering management. Group B; in these patients Tramadol $0.5 \mathrm{mg} / \mathrm{kg}$ I/V was given and Group C (control group); in these patients normal saline $0.05 \mathrm{ml} / \mathrm{kg}$ I/V was given.

Patients undergoing general anesthesia were given nalbuphine $0.1 \mathrm{mg} / \mathrm{kg}$ before induction and then sodium thiopental 3-6 mg/kg intravenously over 1 minute until loss of eyelash reflex, atracurium $0.5 \mathrm{mg} / \mathrm{kg}$ for tracheal intubation, and halothane anesthetic. If necessary, atracurium $0.1 \mathrm{mg} / \mathrm{kg}$ increments were administered. Inhalational agents were stopped once the incision was closed, and leftover muscle relaxants were reversed with neostigmine and atropine, and the trachea was extubated. All patients in the recovery room were monitored and given $\mathrm{O}_{2}$ via a face mask while being wrapped in a blanket. 
Patients who were about to get spinal anesthesia were given crystalloid solution before induction. All patients were put supine after receiving 0.75 percent bupivacaine at the L3-4 or L4-5 interspaces. The torso and upper limbs were covered with a blanket. Supplemental oxygen at a rate of 6 litres per minute was delivered through a Hudson mask.

The adequate control of shivering was the main study objective. The data was entered and analyze into SPSS version 25). Analysis of variance (ANOVA) was used to compare mean significant difference among groups for above mention numeric variables. Chi-square test was also applied to compare proportion difference among groups for side effect and shivering. $P \leq 0.05$ was considered level of significant.

\section{RESULTS}

Mean age, weight and temperature were not significantly different among groups ( $P$-value $>0.05)$. Similarly heart rate, blood pressure and oxygen saturation were also showed no significant difference among groups (ANOVA; $P>0.05)$. Out of 120 patients, 57(47.5\%) were male and $63(52.5 \%)$ were female with $1: 1.1$ male to female ratio. Proportions of gender were not statistically significant among groups ( $p$-value 0.27). ASA physical status of patients according to groups is presented in figure 8 . Significant difference was also not found in ASA status among groups (P-value 0.94) [Table 1].

The proportion of patients with nausea among groups was not statistically significant. Similarly, the proportion of patients with vomiting among groups was also not statistically significant. There was no difference in the incidence of side effect among the three groups at 15 minutes after anesthesia0. At base line, proportion of patients with grade 3 and 4 shivering was recorded among groups. Incident of grade 4 shivering was significantly high in group $A$ and in group $B$ than group $C$ as shown in table 5 (p-value 0.028) [Table 2].

Table 1. Comparison of Demographic and Metabolic Variables Among Groups

\begin{tabular}{|c|c|c|c|c|}
\hline Variables & $\begin{array}{l}\text { Group A } \\
n=40\end{array}$ & $\begin{array}{l}\text { Group B } \\
n=40\end{array}$ & $\begin{array}{l}\text { Group C } \\
n=40\end{array}$ & $\begin{array}{l}\text { P- } \\
\text { Value } \\
\text { s }\end{array}$ \\
\hline $\begin{array}{l}\text { Age } \\
\text { (Years) }\end{array}$ & $33.03 \pm 11.27$ & $33.63 \pm 11.14$ & $34.45 \pm 12.8$ & 0.86 \\
\hline $\begin{array}{l}\text { Weight } \\
(\mathrm{kg})\end{array}$ & $62.33 \pm 9.16$ & $64.00 \pm 9.28$ & $64.08 \pm 9.8$ & 0.64 \\
\hline $\begin{array}{l}\text { Temperatu } \\
\text { re }\left({ }^{\circ} \mathrm{F}\right)\end{array}$ & $98.61 \pm 0.46$ & $98.57 \pm 0.42$ & $98.47 \pm 0.53$ & 0.43 \\
\hline $\begin{array}{l}\text { SBP } \\
(\mathrm{mmHg})\end{array}$ & $118.98 \pm 12.64$ & $126.03 \pm 13.58$ & $122.85 \pm 14.4$ & 0.07 \\
\hline $\begin{array}{l}\text { DBP } \\
(\mathrm{mmHg})\end{array}$ & $73.78 \pm 9.92$ & $75.68 \pm 6.66$ & $76.75 \pm 15.1$ & 0.48 \\
\hline Heart Rate & $90.15 \pm 14.14$ & $91.28 \pm 15.34$ & $90.38 \pm 16.7$ & 0.94 \\
\hline Spo2 & $98.18 \pm 0.55$ & $97.38 \pm 2.22$ & $97.80 \pm 2.6$ & 0.21 \\
\hline \multicolumn{5}{|l|}{ Gender } \\
\hline Male & $20(50 \%)$ & $15(37.5 \%)$ & $22(55 \%)$ & \multirow{2}{*}{0.27} \\
\hline Female & $20(50 \%)$ & $25(62.5 \%)$ & $18(45 \%)$ & \\
\hline \multicolumn{5}{|l|}{ ASA Status } \\
\hline 1 & $33(82.5 \%)$ & $33(82.5 \%)$ & $32(80.0 \%)$ & \multirow{2}{*}{0.94} \\
\hline II & $7(17.5 \%)$ & $7(17.5 \%)$ & $8(20.0 \%)$ & \\
\hline
\end{tabular}

At five minutes, Grade 0,1 and 2 shivering were observed in 23 patients in group $A$ and 31 patients in group $B$ while in group $C$ grade 3 and 4 shivering were observed.
High grade (3 and 4 ) shivering were significantly high in group $C$ than group $A$ and $B(p$-value $=0.005)$ as shown in table 6 . Similarly at 10 minutes, grade 3 and 4 shivering were significantly high in group $C$ than group $A$ and $B$ ( $p$ value 0.005 ) as shown in table 3 .

Table 2. Comparison of Side Effects Between the Groups.

\begin{tabular}{|l|l|l|l|l|}
\hline Side Effect & Group A & Group B & Group C & P-Values \\
\hline NAUSEA & 1 & 2 & 0 & 0.35 \\
\hline Base Line & 2 & 6 & 3 & 0.27 \\
\hline At 5 Min & 2 & 6 & 3 & 0.27 \\
\hline At 10 Min & 2 & 6 & 3 & 0.27 \\
\hline At 15 Min & 2 & 0 & ----- \\
\hline VOMITING & 0 & 0 & 0 & 0.36 \\
\hline Base Line & 0 & 0 & 1 & 0.13 \\
\hline At 5 Min & 0 & 0 & 2 & 0.13 \\
\hline At 10 Min & 0 & 0 & 2 & \\
\hline At 15 Min &
\end{tabular}

Table 3. Comparison for Shivering Among Groups.

\begin{tabular}{|c|c|c|c|c|}
\hline $\begin{array}{l}\text { Shivering } \\
\text { Grade }\end{array}$ & Group A & Group B & Group C & P-value \\
\hline \multicolumn{5}{|l|}{ Baseline } \\
\hline 2 & $0(0.0 \%)$ & $0(0.0 \%)$ & $0(0.0 \%)$ & \multirow[b]{3}{*}{0.028} \\
\hline 3 & $11(27.5 \%)$ & $4(10 \%)$ & $14(35 \%)$ & \\
\hline 4 & $29(72.5 \%)$ & $36(90 \%)$ & $26(65 \%)$ & \\
\hline \multicolumn{5}{|c|}{ At 5 minutes } \\
\hline 0 & $6(15 \%)$ & $6(15 \%)$ & $0(0.0 \%)$ & \multirow[b]{5}{*}{0.005} \\
\hline 1 & $10(25 \%)$ & $15(37.5 \%)$ & $0(0.0 \%)$ & \\
\hline 2 & $7(17.5 \%)$ & $6(15 \%)$ & $0(0.0 \%)$ & \\
\hline 3 & $16(40 \%)$ & $13(32.5 \%)$ & $30(75 \%)$ & \\
\hline 4 & $1(2.5 \%)$ & $0(0.0 \%)$ & $10(25 \%)$ & \\
\hline \multicolumn{5}{|c|}{ At 10 minutes } \\
\hline 0 & $24(60 \%)$ & $25(62.5 \%)$ & $0(0.0 \%)$ & \multirow[b]{5}{*}{0.005} \\
\hline 1 & $12(30 \%)$ & $9(22.5 \%)$ & $0(0.0 \%)$ & \\
\hline 2 & $2(5 \%)$ & $5(12.5 \%)$ & $2(5 \%)$ & \\
\hline 3 & $2(5 \%)$ & $1(2.5 \%)$ & $29(72.5 \%)$ & \\
\hline 4 & $0(0.0 \%)$ & $0(0.0 \%)$ & $9(22.5 \%)$ & \\
\hline \multicolumn{5}{|c|}{ At 15 minutes } \\
\hline 0 & $40(100 \%)$ & $40(100 \%)$ & $1(2.5 \%)$ & \multirow[b]{5}{*}{0.005} \\
\hline 1 & $0(0.0 \%)$ & $0(0.0 \%)$ & $0(0.0 \%)$ & \\
\hline 2 & $0(0.0 \%)$ & $0(0.0 \%)$ & $4(10.0 \%)$ & \\
\hline 3 & $0(0.0 \%)$ & $0(0.0 \%)$ & $22(55 \%)$ & \\
\hline 4 & $0(0.0 \%)$ & $0(0.0 \%)$ & $13(32.5 \%)$ & \\
\hline
\end{tabular}

\section{DISCUSSION}

Shivering is a side effect of anesthesia that is determined by the kind of anesthetic administered. Shivering is related with halothane, enflurane, and isoflurane at a rate of above $60 \%$. The incidence of opioid and nitrous oxide-based anesthesia is only half that of halothane-based anesthesia maintenance. Shivering after anesthesia is often preceded by core hypothermia, although it may also occur with normothermia towards the conclusion of operation.9,10 Shivering may be prevented using equipment that maintains normothermia, although it is costly and not practicable in many situations. Morbid cardiac outcomes linked to moderate perioperative hypothermia seem to be mediated by a mechanism other than shivering, such as a significant rise in plasma catecholamine concentrations. ${ }^{11,12}$

The mechanism of shivering when under anesthesia is unknown. A drop in core temperature and miscommunication from receptors are two possible contributors. (1) Sympathetic blockade causes peripheral vasodilation, increased cutaneous blood flow, and greater heat loss via the skin, resulting in a drop in core temperature. (2) the direct effects of anesthesia on the thermoregulatory center (3) a cool operating room or quick 
infusion of crystalloid solutions at room temperature. Furthermore, local anesthetics injected into the extradural region may alter external thermal signals, resulting in improper thermal reactions to erroneous data. ${ }^{13,14}$

Our research was done to standardize these potentially confounding characteristics while also representing our institution's regular practice. The operating room temperature was kept at $24^{\circ} \mathrm{C}$, intravenous fluids and medicines were given at room temperature, and all patients were given a double layer blanket to cover their upper body. At the start of the procedure, the body temperature was also taken. Tramadol is an analgesic with opioid receptor agonist characteristics. ${ }^{10,11}$ Tramadol also stimulates the descending spinal inhibitory pain pathway's monoaminergic receptors. Tramadol's major opioid impact is mediated via the $\mathrm{u}$-receptor, with a little effect at the $\mathrm{K}$ receptor. Tramadol also blocks synaptosomal, adrenaline, and serotonin absorption, contributing to its analgesic impact. Tramadol, at a dosage as low as $0.25 \mathrm{mg} / \mathrm{kg}$, effectively reduced shivering in patients undergoing regional or postoperative general anesthesia, according to our findings. There was no difference in responsiveness between tramadol doses of $0.5 \mathrm{mg} / \mathrm{kg}$ and $0.25 \mathrm{mg} / \mathrm{kg}$. We changed our dosage regimen from $0.5 \mathrm{mg} / \mathrm{kg}$ to $0.25 \mathrm{mg} / \mathrm{kg}$ tramadol, based on the minimal effective dose of meperidine in reducing shivering. The injection of 0.25 $\mathrm{mg} / \mathrm{kg}$ and $0.5 \mathrm{mg} / \mathrm{kg}$ tramadol $\mathrm{i} / \mathrm{v}$ did not result in a greater rate of adverse effects as compared to normal saline in this investigation. As a result, it's quite probable that tramadol's anti-shivering action was mediated by its noradrenergic or serotonergic activity, or both. Tramadol, on the other hand, has benefits that it is not a restricted substance and induces less respiratory depression and drowsiness at equal doses than other opioids. $0.25 \mathrm{mg} / \mathrm{kg}$ tramadol $\mathrm{i} / \mathrm{v}$ efficiently reduced shivering with little adverse effects, according to our findings. The therapeutic impact of tramadol was not improved by increasing the dosage to 0.5 $\mathrm{mg} / \mathrm{kg} \cdot{ }^{15,16}$

\section{CONCLUSION}

IV $0.25 \mathrm{mg} / \mathrm{Kg}$ is an effective option for control of postanesthesia shivering with minimal side effect profile. So low dose tramadol can be used as a first option for postanesthesia shivering control.

\section{REFERENCES}

1. Lopez MB. Postanaesthetic shivering - from pathophysiology to prevention. Rom $J$ Anaesth Intensive Care. 2018;25(1):73-81.

2. Choi KE, Park B, Moheet AM, Rosen A, Lahiri S, Rosengart A. systematic quality assessment of published antishivering protocols. Anesth Analg. 2017;124(5):1539-46.
3. Prasad RB, Joel CJ, Zachariah VK. Effectiveness of addition of intrathecal tramadol with hyperbaric bupivacaine in prevention of shivering in parturients undergoing caesarean section under spinal anaesthesia: A randomized placebocontrolled study. Karnataka Anaesth J. 2015;1(1):123-7.

4. Lakhe G, Adhikari KM, Khatri K, Maharjan A, Bajracharya A, Khanal H. Prevention of Shivering during Spinal Anesthesia: Comparison between Tramadol, Ketamine and Ondansetron. JNMA J Nepal Med Assoc. 2017;56(208):395400.

5. Nain $P$, Kundra $S$, Singh $T$, Singh $M R$, Kapoor $R$, Singh A. Comparative evaluation of oral tramadol and gabapentin for prophylaxis of post-spinal shivering. Indian J Anaesth. 2021;65(Suppl 1):S5-S11.

6. Mittal G, Gupta K, Katyal S, Kaushal S. Randomised doubleblind comparative study of dexmedetomidine and tramadol for post-spinal anaesthesia shivering. Indian J Anaesth. 2014;58(3):257-62.

7. Vyas V, Gupta R, Dubey P. Comparative Efficacy and Safety of Intravenous Clonidine and Tramadol for Control of Postspinal Anesthesia Shivering. Anesth Essays Res. 2018;12(3):663-668.

8. Wang J, Wang Z, Liu J, Wang N. Intravenous dexmedetomidine versus tramadol for treatment of shivering after spinal anesthesia: a meta-analysis of randomized controlled trials. BMC Anesthesiol. 2020;20(1):104.

9. Kaya M, Sariyildiz O, Karakus D, Ozalp G, Kadiogullari DN. Tramadol versus meperidine in the treatment of shivering during spinal anaesthesia. Eur $J$ Anaesthesiol. 2003;20(4):332-3.

10. Luggya TS, Kabuye RN, Mijumbi C, Tindimwebwa JB, Kintu A. Prevalence, associated factors and treatment of post spinal shivering in a Sub-Saharan tertiary hospital: a prospective observational study. BMC Anesthesiol. 2016;16(1):100.

11. Park FD, Park S, Chi SI, Kim HJ, Seo KS, Kim HJ, et al. Clinical considerations in the use of forced-air warming blankets during orthognathic surgery to avoid postanesthetic shivering. J Dent Anesth Pain Med. 2015;15(4):193-200.

12. Tyvold SS. Preventing hypothermia in outpatient plastic surgery by self-warming or forced-air-warming blanket: A randomised controlled trial. Eur $\mathrm{J}$ Anaesthesiol. 2019;36(11):843-50.

13. Tsai YC, Chu KS. A comparison of tramadol, amitriptyline, and meperidine for postepidural anesthetic shivering in parturients. Anesth Analg.2001;93:1288-92.

14. Sriranganath $T$, Radhapuram $S$, Rao $M$, Shameem $S$, Samantaray A, Dharaniprasad G. Comparison of intravenous tramadol and intravenous ketamine for the prevention of post-anaesthetic shivering. Journal of Clinical and Scientific Research. 2020;9(2):94-9.

15. Atashkhoyi S, Negargar S. Effect of tramadol for prevention of shivering after spinal anaesthesia for caesarean section. Res J Biol Sci. 2008;3(12):1365-9.

16. Nakagawa T, Hashimoto M, Hashimoto $Y$, Shirozu K, Hoka $\mathrm{S}$. The effects of tramadol on postoperative shivering after sevoflurane and remifentanil anesthesia. BMC Anesthesiol. 2017;17(1):1. 